\title{
The last deglaciation: timing the bipolar seesaw
}

\author{
J. B. Pedro ${ }^{1,2}$, T. D. van Ommen ${ }^{1,3}$, S. O. Rasmussen ${ }^{4}$, V. I. Morgan ${ }^{1,3}$, J. Chappellaz ${ }^{5}$, A. D. Moy ${ }^{1,3}$, \\ V. Masson-Delmotte ${ }^{6}$, and M. Delmotte ${ }^{6}$ \\ ${ }^{1}$ Antarctic Climate \& Ecosystems Cooperative Research Centre, Hobart, Tasmania, Australia \\ ${ }^{2}$ Institute of Marine and Antarctic Studies, University of Tasmania, Hobart, Tasmania, Australia \\ ${ }^{3}$ Australian Antarctic Division, Kingston, Tasmania, Australia \\ ${ }^{4}$ Centre for Ice and Climate, University of Copenhagen, Copenhagen, Denmark \\ ${ }^{5}$ Laboratoire de Glaciologie et Géophysique de l'Environnement, Saint Martin d'Hères, France \\ ${ }^{6}$ Laboratoire des Sciences du Climat et de l'Environnement, Saclay, France
}

Received: 21 January 2011 - Published in Clim. Past Discuss.: 26 January 2011

Revised: 4 June 2011 - Accepted: 7 June 2011 - Published: 24 June 2011

\begin{abstract}
Precise information on the relative timing of north-south climate variations is a key to resolving questions concerning the mechanisms that force and couple climate changes between the hemispheres. We present a new composite record made from five well-resolved Antarctic ice core records that robustly represents the timing of regional Antarctic climate change during the last deglaciation. Using fast variations in global methane gas concentrations as time markers, the Antarctic composite is directly compared to Greenland ice core records, allowing a detailed mapping of the inter-hemispheric sequence of climate changes. Consistent with prior studies the synchronized records show that warming (and cooling) trends in Antarctica closely match cold (and warm) periods in Greenland on millennial timescales. For the first time, we also identify a sub-millennial component to the inter-hemispheric coupling. Within the Antarctic Cold Reversal the strongest Antarctic cooling occurs during the pronounced northern warmth of the Bølling. Warming then resumes in Antarctica, potentially as early as the Intra-Allerød Cold Period, but with dating uncertainty that could place it as late as the onset of the Younger Dryas stadial. There is little-to-no time lag between climate transitions in Greenland and opposing changes in Antarctica. Our results lend support to fast acting inter-hemispheric coupling mechanisms, including recently proposed bipolar atmospheric teleconnections and/or rapid bipolar ocean teleconnections.
\end{abstract}

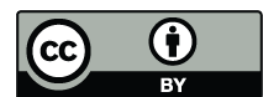

Correspondence to: J. B. Pedro (jbpedro@utas.edu.au)

\section{Introduction}

The last deglaciation (ca. 19 to 11 thousand years before present (ka BP), where present is defined as 1950) is the most recent example of a major naturally forced global climate change. Previous studies confirm opposing climate trends on millennial timescales between the northern and southern mid to high-latitudes during this interval (e.g. Sowers and Bender, 1995; Blunier et al., 1998; Blunier and Brook, 2001; Shakun and Carlson, 2010; Kaplan et al., 2010). Antarctica first warmed during the glacial conditions of Greenland stadial 2 (GS-2), then cooled during the Antarctic Cold Reversal (ACR), as Greenland experienced the warmth of the BøllingAllerød interstadial (B-A or GI-1a-e). Antarctica then resumed warming as Greenland returned to the near-glacial conditions of the Younger Dryas stadial (YD or GS-1).

The conventional explanation for these opposing climate trends is the bipolar ocean seesaw; it proposes that the two hemispheres are coupled via oscillations in the dominant direction of heat transport in the Atlantic Ocean due to perturbations in the meridional overturning circulation (Broecker, 1998). More recently, an alternate (though potentially complimentary) mechanism has been put forward that invokes atmospheric teleconnections in forcing the bipolar coupling (Anderson et al., 2009 and references therein). Sorting out the relative contributions of oceanic and atmospheric processes is critical for understanding Earth's climate dynamics. A key role of the palaeoclimate record is to provide firm observational constraints against which these dynamical mechanisms and their timescales can be tested.

We begin by constructing a new climate chronology for the last deglaciation from the Law Dome (LD) ice core, Coastal East Antarctica, based on synchronization of fast methane variations at LD with those from Greenland (on

Published by Copernicus Publications on behalf of the European Geosciences Union. 


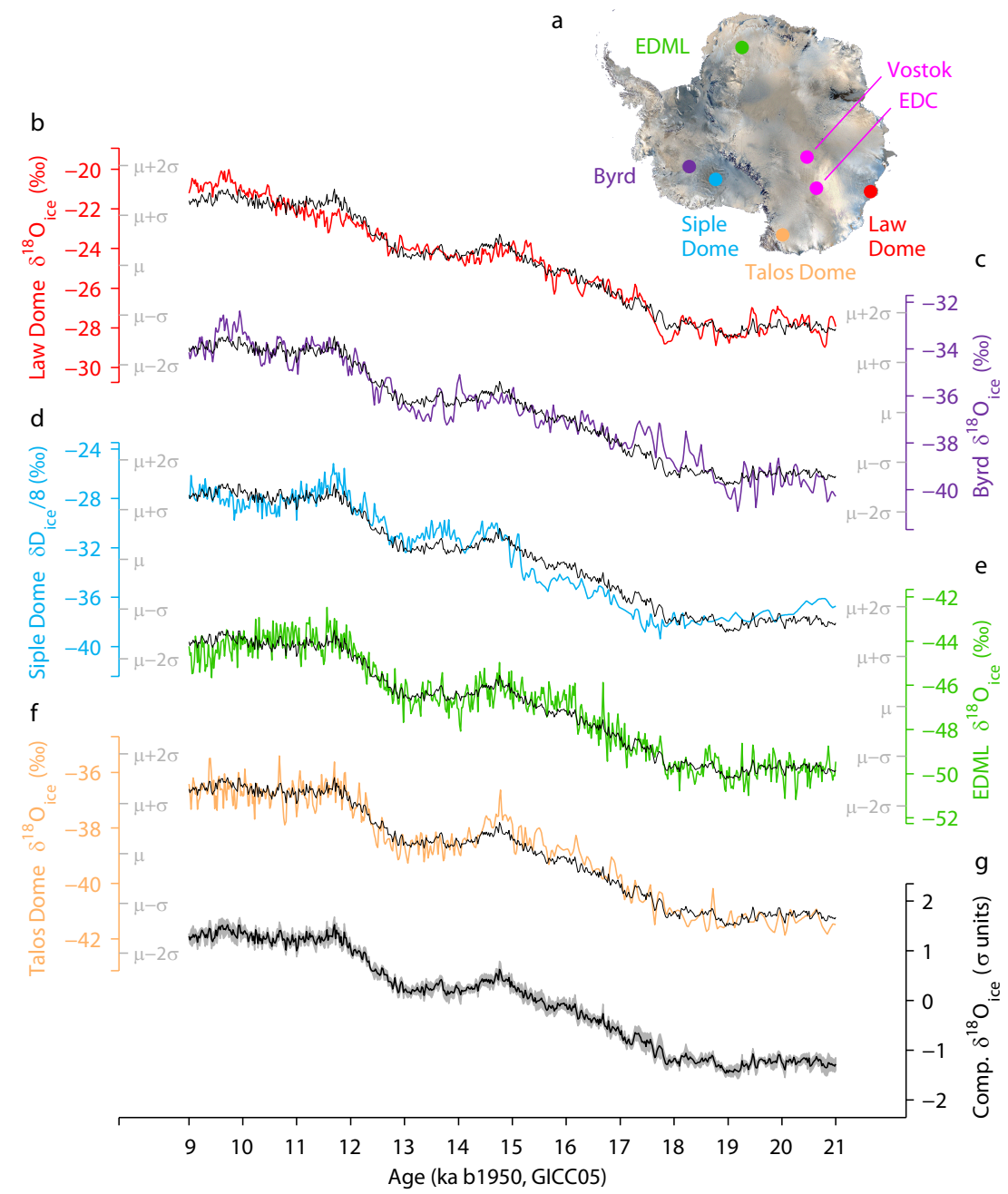

Fig. 1. $\delta^{18} \mathrm{O}_{\text {ice }}$ records from high-accumulation/near-coastal sites used to construct the Antarctic composite. (a) Map showing the location of the ice cores used and other records mentioned in the text (source: NASA). (b)-(f) Deglacial $\delta^{18} \mathrm{O}_{\text {ice }}$ records from LD, Byrd, Siple Dome, Talos Dome, and EDML all placed on the common GICC05 timescale; the individual vertical axes are scaled according to the standard deviation of each record, as can be seen from the inner $\sigma$ axis labels (in grey). (g) The Antarctic composite $\delta^{18} \mathrm{O}_{\text {ice }}$ (black, also overlain in panels (b)-(e)) is shown bracketed by the standard error in the mean of the $\delta^{18} \mathrm{O}_{\text {ice }}$ records from the five sites (grey shading). Estimated dating uncertainty in the composite (relative to GICC05) is $380 \mathrm{yr}, 200 \mathrm{yr}$, and $220 \mathrm{yr}$ for intervals 15 to $18 \mathrm{ka} \mathrm{BP}, 13$ to $15 \mathrm{ka} \mathrm{BP}$, and 10 to $13 \mathrm{ka} \mathrm{BP}$, respectively. Note that for Siple Dome the actual $\delta^{18} \mathrm{O}_{\text {ice }}$ values were not available, so we use an appropriately scaled version of $\delta \mathrm{D}_{\text {ice }}$ (see Appendix A).

the Greenland Ice Core Chronology 2005, GICC05 (Rasmussen et al., 2008). As with all ice core $\delta^{18} \mathrm{O}_{\text {ice }}$ records, the LD record has been interpreted principally as a record of local temperature variations, notwithstanding that $\delta^{18} \mathrm{O}_{\text {ice }}$ may also be influenced by changes in other variables, including temperature/humidity at the oceanic moisture source, seasonal distribution of snow fall, surface elevation, and anomalous ice flow (e.g. Jones et al., 2009). Construction of composite $\delta^{18} \mathrm{O}_{\text {ice }}$ records from multiple ice cores has been demonstrated previously to reduce these local signals and produce reconstructions that more robustly represent regional climate trends (e.g. White et al., 1997; Andersen et al., 2006a). Therefore, in order to represent climate evolu- tion in the broader Antarctic region, we construct a $\delta^{18} \mathrm{O}_{\text {ice }}$ composite from the LD record and records from other highaccumulation/near-coastal sites: Byrd (Blunier and Brook, 2001), Siple Dome (Brook et al., 2005), Talos Dome (Stenni et al., 2011; Buiron et al., 2011), and EPICA Dronning Maud Land (EDML) (EPICA c.m., 2006; Lemieux-Dudon et al., 2010). These five cores are selected since they sample from a wide geographic range, including the Indian (LD), Atlantic (EDML), and Pacific (Siple Dome, Byrd, Talos Dome) sectors of the Antarctic continent (Fig. 1a), and because they can all be methane-synchronized with the GICC05 timescale of the central Greenland ice cores with sufficient accuracy. 
Table 1. Site characteristics and $\triangle$ age values during modern, ACR, and LGM times at the Antarctic ice core sites mentioned in the text.

\begin{tabular}{llrrrrr}
\hline Site & Location & $\begin{array}{r}\text { Elevation } \\
(\mathrm{m} \text { a.s.l. })\end{array}$ & $\begin{array}{r}\text { Distance from } \\
\text { ocean }^{(\mathrm{km})}\end{array}$ & $\begin{array}{r}\Delta \text { age } \\
\text { modern }(\mathrm{yr})\end{array}$ & $\begin{array}{r}\Delta \text { age at } \\
\text { ACR }(\mathrm{yr})\end{array}$ & $\begin{array}{r}\Delta \text { age at } \\
\text { LGM }(\mathrm{yr})\end{array}$ \\
\hline LD & $66^{\circ} 46^{\prime} \mathrm{S}, 112^{\circ} 48^{\prime} \mathrm{E}$ & 1370 & 100 & 60 & 350 & 700 \\
Byrd $^{\mathrm{a}}$ & $80^{\circ} 01^{\prime} \mathrm{S}, 119^{\circ} 31^{\prime} \mathrm{W}$ & 1530 & 591 & 270 & 380 & 480 \\
Siple $^{\mathrm{b}}$ & $81^{\circ} 40^{\prime} \mathrm{S}, 148^{\circ} 49^{\prime} \mathrm{W}$ & 621 & 439 & 242 & 381 & 815 \\
Talos $^{\mathrm{c}}$ & $72^{\circ} 49^{\prime} \mathrm{S}, 159^{\circ} 11^{\prime} \mathrm{E}$ & 2315 & 250 & 675 & 920 & 1595 \\
EDML $^{\mathrm{d}}$ & $75^{\circ} 00^{\prime} \mathrm{S}, 00^{\circ} 04^{\prime} \mathrm{E}$ & 2892 & 577 & 800 & 1200 & 2300 \\
EDC $^{\mathrm{e}}$ & $74^{\circ} 39^{\prime} \mathrm{S}, 124^{\circ} 10^{\prime} \mathrm{E}$ & 3240 & 912 & 2400 & 3000 & 4500 \\
Vostok $^{\mathrm{f}}$ & $78^{\circ} 28^{\prime} \mathrm{S}, 106^{\circ} 48^{\prime} \mathrm{E}$ & 3490 & 1409 & 3300 & 4400 & 5200 \\
\hline
\end{tabular}

Source of $\Delta$ age and elevation data: ${ }^{a}$ Blunier and Brook (2001), ${ }^{b}$ Brook et al. (2005), ${ }^{\mathrm{c}}$ Stenni et al. (2011), ${ }^{\mathrm{d}}$ Lemieux-Dudon et al. (2010), ${ }^{\mathrm{e}}$ Parrenin et al. (2007), ${ }^{\mathrm{f}}$ Goujon et al. (2003), ${ }^{\mathrm{g}}$ Timmermann et al. (2010) (with ice shelves considered part of the continent).

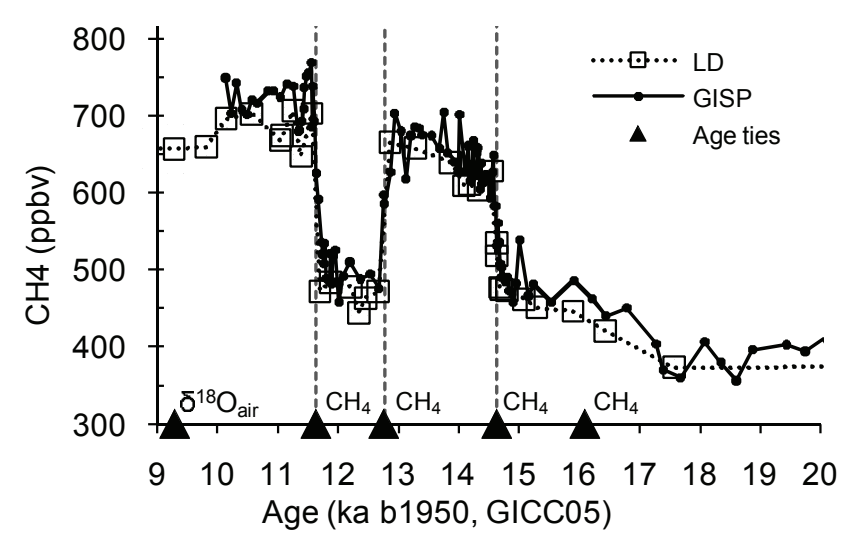

Fig. 2. Dating of the LD ice core through the deglaciation. LD methane is synchronised with GISP2 methane (Blunier and Brook, 2001) on the GICC05 timescale. Timing of methane transitions at the onset of the Bølling, Younger Dryas, and Holocene are shown as dashed vertical lines. Triangles mark the position and type of the dating ties used through the deglaciation. Standard error in LD methane concentrations are $\leq 20 \mathrm{ppm}$.

The accuracy of the methane synchronization technique is limited by the offset between the age of the ice and the age of bubbles at a certain depth (i.e. the $\Delta$ age; a result of the bubbles being sealed off from contact with the atmosphere at a depth of 50 to $100 \mathrm{~m}$ during the transformation of snow to ice). Compared to the cores from the East Antarctic Plateau (e.g. EPICA Dome C (EDC) and Vostok), the relatively high accumulation records used here have more accurately constrained, and lower $\Delta$ ages, by up to an order of magnitude (Table 1), leading to greater precision in the methane synchronization.

The robust Antarctic-wide climate signal that emerges in the composite is used to provide tighter constraints on the relative timing of north-south climate variations during the deglaciation.

\section{Methods}

\subsection{Construction of the revised Law Dome $\delta^{18} O_{\text {ice }}$ chronology}

The previous LD methane record (Morgan et al., 2002) is supplemented here with additional measurements that improve our timing constraints. Additional $\delta^{18} \mathrm{O}_{\text {ice }}$ measurements were also made on the LD record, improving its temporal resolution to an average of $25 \mathrm{yr}$ per sample for the interval 9 to $21 \mathrm{ka} \mathrm{BP}$.

The LD $\delta^{18} \mathrm{O}_{\text {ice }}$ record was placed on the GICC05 timescale by synchronizing the $\mathrm{LD} \mathrm{CH}_{4}$ variations with GISP2 $\mathrm{CH}_{4}$ variations on the GICC05 time scale. To obtain GISP2 $\mathrm{CH}_{4}$ on GICC05, the GISP2 $\mathrm{CH}_{4}$ record on the ss09 time scale (reported in Blunier and Brook., 2001) was linearly interpolated to GRIP depths using the ss09 age-depth relation (Johnsen et al., 1997), and then to GICC05 ages by linear interpolation using stratigraphical markers (Rasmussen et al., 2008).

Figure 2 shows the GISP2 methane record and the new LD methane record. Also shown are the timings of the abrupt onsets of the Bølling, YD, and Holocene climate stages, as derived from the stable isotope records of the annually layer counted GRIP, NGRIP, and GISP2 ice cores (Rasmussen et al., 2006; Andersen et al., 2006b; Steffensen et al., 2008). The timing of methane transitions is considered to be synchronous with the onsets of these climate stages. The LD gas age scale was tied to GICC05 at the times of these methane transitions. On the older side of the deglaciation, the midpoint of the slow deglacial rise in methane (through the interval ca. 17.5 to $15 \mathrm{ka} \mathrm{BP}$ ) is used as a tie. We also used methane ties to GISP2 during Dansgaard-Oeschger events 7 and 8 (35.48 and $38.22 \mathrm{ka} \mathrm{BP}$, respectively). On the younger side of the deglaciation we use a $\delta^{18} \mathrm{O}_{\text {air }}$ tie to GISP2 and GRIP (9.30 ka BP).

The gas age ties were converted to ice age ties by adding an estimate of the difference between the age of the gas and the age of the ice (i.e. the $\Delta$ age). We estimated $\Delta$ age 
Table 2. LD age ties used in construction of the deglacial chronology and their uncertainties.

\begin{tabular}{llccc}
\hline Type & $\begin{array}{l}\text { LD } \\
\text { depth } \\
(\mathrm{m})\end{array}$ & $\begin{array}{l}\text { LD GICC05 } \\
\text { gas age } \pm \sigma_{\text {correl }} \\
(\mathrm{kab1950)}\end{array}$ & $\begin{array}{l}\Delta \text { age } \\
\pm \sigma_{\Delta \text { age }} \\
(\mathrm{yr})\end{array}$ & $\begin{array}{l}\text { LD } \\
\text { ice age } \pm \sigma_{\text {ice }} \\
(\mathrm{kab} 1950)\end{array}$ \\
\hline$\delta^{18} \mathrm{O}_{\text {air }}$ & 1108.64 & $9.30 \pm 0.15$ & $119 \pm 36$ & $9.42 \pm 0.15$ \\
$\mathrm{CH}_{4}:$ Start of Holocene & 1121.29 & $11.63 \pm 0.08$ & $148 \pm 43$ & $11.78 \pm 0.09$ \\
$\mathrm{CH}_{4}:$ Start of GS-1 & 1125.19 & $12.77 \pm 0.10$ & $273 \pm 82$ & $13.04 \pm 0.13$ \\
$\mathrm{CH}_{4}:$ Start of GI-1e & 1129.04 & $14.64 \pm 0.03$ & $309 \pm 93$ & $14.94 \pm 0.10$ \\
$\mathrm{CH}_{4}:$ Mid-point of deglacial rise & 1131.75 & $15.65 \pm 0.30$ & $433 \pm 130$ & $16.09 \pm 0.33$ \\
$\mathrm{CH}_{4}:$ DO7 & 1144.28 & $35.34 \pm 0.18$ & $540 \pm 160$ & $35.88 \pm 0.25$ \\
$\mathrm{CH}_{4}:$ DO8 & 1146.70 & $38.34 \pm 0.20$ & $500 \pm 150$ & $38.84 \pm 0.25$ \\
\hline
\end{tabular}

$\sigma_{\text {correl }}$ refers to the uncertainty involved in correlating the $\mathrm{LD} \mathrm{CH}_{4}$ record with the GISP2 $\mathrm{CH}_{4}$ record; $\sigma_{\Delta \text { age }}$ refers to the uncertainty in $\Delta$ age at $\mathrm{LD}$; and $\sigma_{\text {ice }}$ is calculated as the RMS sum of $\sigma_{\text {correl }}$ and $\sigma_{\Delta \text { age }}$

using the Pimienta firn densification model (Barnola et al., 1991), which requires temperature and accumulation rate input. Surface temperature was estimated from $\delta^{18} \mathrm{O}_{\text {ice }}$ by scaling of the modern temporal (seasonal) relationship between $\delta^{18} \mathrm{O}_{\text {ice }}$ and temperature $(T)$ at Law Dome $\left(\delta^{18} \mathrm{O}_{\text {ice }}\right.$ is proportional to $0.44 T$ ) (van Ommen and Morgan., 1997). Accumulation rates and ages between tie points are calculated using a simple Dansgaard-Johnsen flow model, fitted to the chosen age ties, as discussed elsewhere (van Ommen et al., 2004). The model predicts relatively low accumulation rates at Law Dome during the deglaciation, for instance ca. $20 \%$ of modern at $15 \mathrm{ka} \mathrm{BP}$ and ca. $10 \%$ of modern during the LGM. These model accumulation rates are the most reliable estimates available for LD and they are independently supported by measurements of the deglacial changes in $\delta^{15} \mathrm{~N}_{\text {air }}$ at LD (Landais et al., 2006). An alternate method of estimating paleoaccumulation rate from the water vapor pressure (derived from $\delta^{18} \mathrm{O}_{\text {ice}}$ ) is often used at ice core sites on the East Antarctic Plateau. The water vapor pressure technique is not suited to the Law Dome site where, in contrast to the East Antarctic plateau, the accumulation rate appears to be influenced by cyclonic activity rather than by local temperature controls on the atmospheric moisture content. Problems with the assumed relation between vapor pressure and accumulation are also noted at other near coastal sites (Monnin et al., 2004).

There are two main sources of error in the LD ice age ties: firstly, the uncertainty in our alignment of the fast methane transitions at Law Dome with those at GISP2 (the correlation uncertainty, $\left.\sigma_{\text {correl }}\right)$; and secondly, the uncertainty in the LD $\Delta$ age (which we conservatively estimate as $\pm 30 \%$ of $\Delta$ age, $\left.\sigma_{\Delta \text { age }}\right)$. The gas age ties, $\Delta$ ages, and ice age ties together with their estimated uncertainties are listed in Table 2. We do not include in our error estimates the uncertainty in the GICC05 timescales for the GISP2 gas age ties; rather, we specify that the error in our age ties is relative to the GICC05 timescale.

\subsection{Construction of the Antarctic $\delta^{18} O_{\text {ice }}$ composite record}

In constructing the Antarctic composite, LD, Byrd, Siple Dome, Talos Dome, and EDML, $\delta^{18} \mathrm{O}_{\text {ice }}$ series on their GICC05 timescales (see Appendix A) were interpolated to $20 \mathrm{yr}$ time steps. Note that for Siple Dome the actual deglacial $\delta^{18} \mathrm{O}_{\text {ice }}$ record was not available so we used an appropriately scaled version of $\delta \mathrm{D}_{\text {ice }}$ ice in its place (see Appendix A). For simplicity, when speaking of multiple records, we continue to use the term $\delta^{18} \mathrm{O}_{\text {ice }}$. Each series was standardized over the interval 9 to $21 \mathrm{ka} \mathrm{BP}$ to zero mean and unit standard deviation, and the mean of the five data sets was taken at each time step. Extension of the composite beyond $21 \mathrm{ka} \mathrm{BP}$ is not possible at this stage due to the lack of fast methane variations or other high-quality inter-hemispheric dating ties with which to synchronize the records. Accordingly, our focus here is only on the deglaciation, i.e. the interval beginning with the onset of a coherent Antarctic warming trend and ending with the termination of the warming trend at the start of the Holocene.

\subsection{Statistical analysis of warming and cooling trends}

A statistical approach, SiZer analysis of curvature (Chaudhuri and Marron, 1999), is used to objectively determine the timing of significant climate features in both the LD and Antarctic composite $\delta^{18} \mathrm{O}_{\text {ice }}$ records during the deglaciation.

SiZer applies a series of smoothing filters to the time series (Fig. 3a and c) and depicts the sign of the slope as a function of time and filter width (Fig. $3 b$ and d). We define the onset of deglaciation as the time at which a significant warming is first observed on all timescales (i.e. regardless of the degree of smoothing), the ACR onset is then bracketed by the end of the significant warming trend and the start of a significant cooling trend. Similarly, the ACR termination is bracketed by the end of the significant ACR cooling trend and the resumption of a significant warming trend, and the end of the deglaciation is where the significant warming trend ceases. 

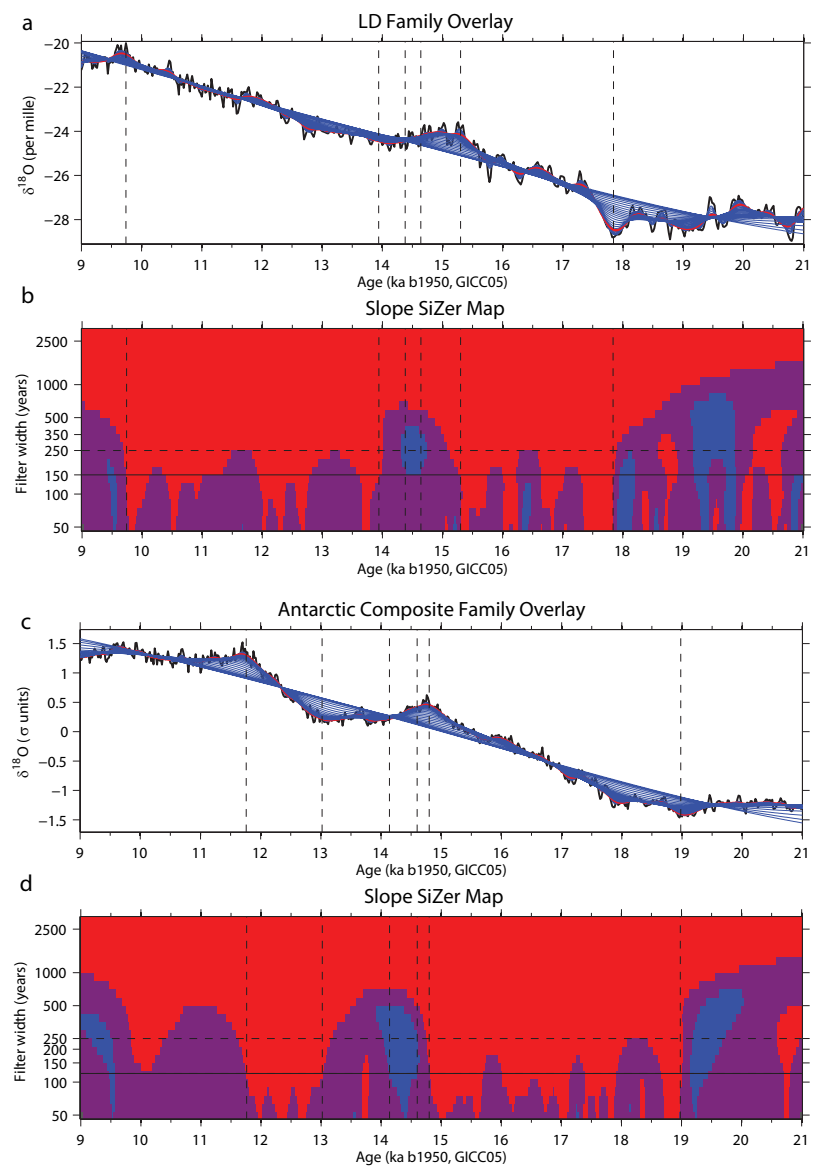

Fig. 3. SiZer maps of the significance of features in $\mathrm{LD} \delta^{18} \mathrm{O}_{\text {ice }}$ and the Antarctic composite through the deglaciation. (a) LD Family Overlay: the series of blue curves shows LD $\delta^{18} \mathrm{O}_{\text {ice }}$ smoothed across a range of filter widths from 40 to $3000 \mathrm{yr}$, the black curves show the original data and the red curve shows the $150 \mathrm{yr}$ smooth. (b) LD Slope Sizer Map: the significance and sign of the slope of the smoothed data is shown, as the filter width (on the vertical axis) is varied; red signifies significant positive slope (warming), blue signifies significant negative slope (cooling), and purple signifies regions where the slope is not statistically different from zero (all with respect to the $95 \% \mathrm{CL}$ ); for instance, the significant cooling during the ACR appears as the blue area in the centre of the figure. The timing of significant climate features at LD is interpreted from the intercepts of the $150 \mathrm{yr}$ smoothing (horizontal solid line) with the changes in the significance and/or sign of the slope (see Sect. 2.3.1). Significant features are marked with dashed vertical lines. The timing and dating uncertainty of climate features are listed in Table 4. (c) Antarctic Composite Family Overlay: interpret as above except that the red curve shows the $120 \mathrm{yr}$ smooth. (d) Antarctic composite Slope SiZer Map: the timing of significant climate features is interpreted from the intercepts of the $120 \mathrm{yr}$ smoothing with the changes in the significance and/or sign of the slope (see Sect. 2.3.2).
In using SiZer for the identification of climate features a decision must be made on the smoothing filter width that preserves a clear signal from the major millennial and submillennial scale climate features of interest, but is above the confounding influence of shorter term noise. Hence the optimal smoothing filter width will depend on the level of noise in the record. As it is an individual core, the level of noise in the LD record is expected to be larger than that of the 5-core Antarctic composite and therefore a wider filter is appropriate for LD compared to the Antarctic composite.

\subsubsection{Law Dome}

For the LD record at filter widths of above $250 \mathrm{yr}$ the deglaciation is seen, on the simplest level, as a warming interrupted by the ACR (dashed horizontal line, Fig. 3b). At filter widths much larger than this the timing of climate features is highly dependent on filter width, which suggests that detection is not robust. Moving to filter widths of $\leq 150 \mathrm{yr}$ the timing of features generally stabilises (below solid line, Fig. 3b). Hence, we select $150 \mathrm{yr}$ as the optimal filter width at which to detect climate features in the LD record (solid horizontal line, Fig. 3b).

\subsubsection{Antarctic composite}

For the composite record, again at filter-widths of above 250 yr the major millennial scale features of the deglaciation are identified (dashed horizontal line, Fig. 3d). Moving to narrower filters, a threshold is seen at a width of $\leq 100 \mathrm{yr}$, at which multiple short term signals that we regard as noise are expressed. To stay above this noise threshold we select $120 \mathrm{yr}$ as the optimal filter width to detect climate features of interest to this work (solid horizontal line, Fig. 3d).

\subsection{Dating uncertainty in the Antarctic composite}

The dating uncertainty of the Antarctic composite ( $\left.\sigma_{\text {Composite }}\right)$ relative to GICC05 includes contributions from the dating uncertainty of the five records $\left(\sigma_{\mathrm{LD}}\right.$ ice, $\left.\sigma_{\text {Byrd ice }}, \sigma_{\text {Siple ice }}, \sigma_{\text {Talos ice }}, \sigma_{\text {EDML ice }}\right)$. In the same way as for $\sigma_{\mathrm{LD}}$ ice (Sect. 2.1), the individual core $\sigma_{\text {ice }}$ values at Byrd and Siple Dome are calculated (following Blunier and Brook (2001)) as the root mean square (RMS) sum of the methane synchronisation $\left(\sigma_{\text {correl }}\right)$ uncertainty and the $\Delta$ age uncertainty $\left(\sigma_{\Delta \text { age }}\right)$ reported by the original authors of each record (Blunier and Brook, 2001, and Brook et al., 2005, respectively). For Talos Dome and EDML we adopt the $\sigma_{\text {ice }}$ values reported with the recent publications of GICC05 consistent timescales for those cores (Buiron et al., 2011, and Lemieux-Dudon et al., 2010, respectively). These uncertainty terms are reported in Table 3.

Combining the uncertainties from the individual cores into one uncertainty value for the composite record is not straightforward: firstly, the uncertainties in the individual records vary with time during the deglaciation; secondly, it cannot 
Table 3. Dating uncertainties in the individual records used in the Antarctic composite during the deglaciation (Sect. 2.4)

\begin{tabular}{|c|c|c|c|c|c|c|c|c|c|}
\hline \multirow[b]{2}{*}{ Core } & \multicolumn{3}{|c|}{$\begin{array}{l}\text { Late deglaciation } \\
(\sim 10-13 \text { ka b1950) }\end{array}$} & \multicolumn{3}{|c|}{$\begin{array}{l}\text { Middle deglaciation } \\
(\sim 13-15 \text { ka b1950) }\end{array}$} & \multicolumn{3}{|c|}{$\begin{array}{l}\text { Early deglaciation } \\
(\sim 15-18 \text { ka b1950) }\end{array}$} \\
\hline & $\sigma_{\text {correl }}$ & $\sigma_{\Delta \mathrm{age}}$ & $\sigma_{\text {ice }}$ & $\sigma_{\text {correl }}$ & $\sigma_{\Delta \mathrm{age}}$ & $\sigma_{\text {ice }}$ & $\sigma_{\text {correl }}$ & $\sigma_{\Delta \text { age }}$ & $\sigma_{\text {ice }}$ \\
\hline LD & 100 & 80 & 128 & 30 & 90 & 95 & 300 & 125 & 325 \\
\hline Byrd $^{\mathrm{a}}$ & 200 & 200 & 283 & 200 & 200 & 283 & 300 & 200 & 361 \\
\hline Siple Dome ${ }^{b}$ & 170 & 110 & 202 & 120 & 130 & 177 & 320 & 190 & 372 \\
\hline Talos $^{\mathrm{c}}$ & - & - & 300 & - & - & 300 & - & - & 500 \\
\hline EDML $^{\mathrm{d}}$ & - & - & 200 & - & - & 140 & - & - & 360 \\
\hline Average & - & - & 223 & - & - & 199 & - & - & 384 \\
\hline
\end{tabular}

${ }^{\mathrm{a}}$ Blunier and Brook (2001), ${ }^{\mathrm{b}}$ Brook et al. (2005), ${ }^{\mathrm{c}}$ Buiron et al. (2011), ${ }^{\mathrm{d}}$ Lemieux-Dudon et al. (2010).

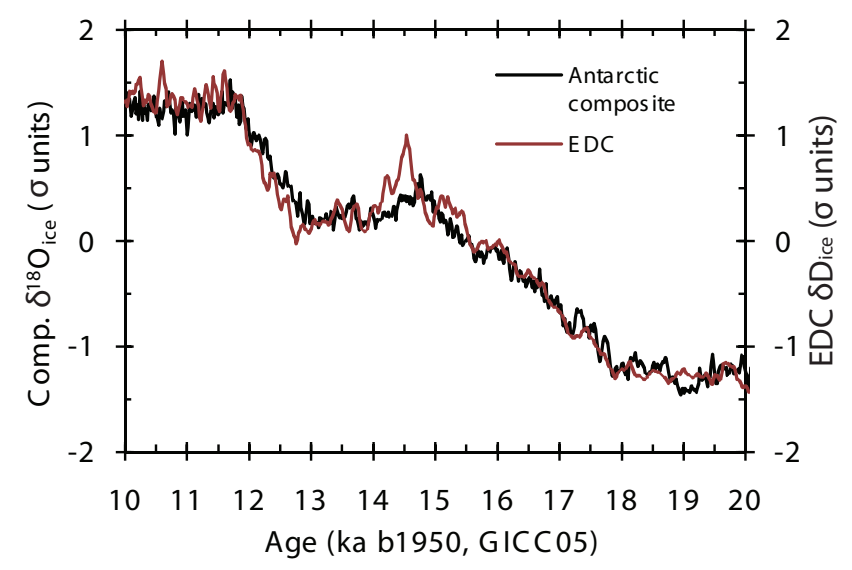

Fig. 4. A comparison of the Antarctic composite with the EPICA Dome C (EDC) $\delta \mathrm{D}_{\text {ice }}$ record. The GICC05 consistent timescale for EDC is from Lemieux-Dudon et al. (2010) and $\delta D_{\text {ice }}$ data are from Jouzel et al. (2001).

be assumed that the individual uncertainties are independent; and thirdly, to our knowledge there is no formal way of combining dating uncertainty in individual records into one dating uncertainty for a composite. These complications prevent us providing any formal "standard error" value for the composite. However, a conservative estimate is that the overall uncertainty is lower than the average of the uncertainty of the individual records.

A "jack-knifing" test, in which the composite was constructed by including all and then leaving out one in turn of the five records, was used to test the robustness of the composite dating. The timing of climate features is essentially unchanged when this technique is applied. For instance, in the resulting 6 versions of the composite, the timing of the pre-ACR isotope maximum (mean $\pm 2 \sigma$ ) is $(14.76 \pm 0.02) \mathrm{kaBP}$. This result supports the robustness of the dating and the presence of a coherent Antarctic-wide climate signal within the five records.

\section{Results and discussion}

Figure 1b shows the LD ice core oxygen isotope record $\left(\delta^{18} \mathrm{O}_{\text {ice }}\right)$ alongside the records from Byrd, Siple Dome, Talos Dome, and EDML, all on the common GICC05 timescale. All records show a similar pattern: an overall warming trend interrupted by the millennial scale ACR. However, the precise timing of changes in climate trends differs between records. This is illustrated by apparent differences in the timing of the onset of the ACR. For instance, at LD the pre-ACR warming trend ends at $15.30 \pm 0.17 \mathrm{kaBP}$ (Table 4), which, within timescale uncertainties, is consistent with the previously published result of Morgan et al. (2002). This is considerably older than at EDML where the pre-ACR warming trend ends at $14.55 \pm 0.13 \mathrm{ka} \mathrm{BP}$ (Lemieux-Dudon et al., 2010). Such differences between cores (which are greater than dating uncertainties) represent the influence of local and/or non-climatic signals at individual sites and underscore the need for caution in interpreting the phasing of interhemispheric climate changes from single-site records.

The Antarctic $\delta^{18} \mathrm{O}_{\text {ice }}$ composite is shown superimposed on the individual records from which it is constructed in Fig. 1b-f, and bracketed by its standard error in Fig. 1g. Deviations between individual records and the composite are indicative of local, non-climatic, and/or sub-continental variations. A clear example of such a deviation is the continued rise in $\delta^{18} \mathrm{O}_{\text {ice }}$ at $\mathrm{LD}$ into the Holocene (until 9.74 \pm $0.15 \mathrm{ka} \mathrm{BP}$ ). Air content measurements on the LD core suggest a lowering of the drill site of 100 to $300 \mathrm{~m}$ (Delmotte et al., 1999), which would be broadly consistent with the change in $\delta^{18} \mathrm{O}_{\text {ice }}$ relative to the other sites. Detailed evaluation of differences between the timing of climate variations in the composite and records from the East Antarctic Plateau including EDC, Vostok, and Dome Fuji is hampered by the relatively large dating uncertainties of these low accumulation records. Nevertheless, a recent revision of the EDC dating to a GICC05-consistent timescale (Lemieux-Dudon et al., 2010) permits a comparison to be made (Fig. 4). Very close agreement between the records is observed through the onset 
Table 4. The timing of climate features in the LD and Antarctic composite $\delta^{18} \mathrm{O}$ records derived from SiZer analysis. Dating uncertainties are the RMS sum of the dating uncertainty and uncertainty in the statistical method for picking timing of the climate feature (Sect. 2.3).

\begin{tabular}{lcl}
\hline Climate feature & LD Age (ka b1950) & Composite Age (ka b1950) \\
\hline Start deglacial warming & $17.84 \pm 0.32$ & $18.98 \pm 0.50$ \\
End warming (earliest ACR onset) & $15.30 \pm 0.17$ & $14.80 \pm 0.20$ \\
Start cooling (latest ACR onset) & $14.64 \pm 0.10$ & $14.60 \pm 0.20$ \\
End cooling (earliest ACR termination) & $14.38 \pm 0.11$ & $14.14 \pm 0.20$ \\
Start warming (latest ACR termination) & $13.94 \pm 0.12$ & $13.02 \pm 0.20$ \\
End deglacial warming & $9.74 \pm 0.15$ & $11.76 \pm 0.22$ \\
\hline
\end{tabular}

of the deglaciation (ca. 19 to $15 \mathrm{ka} \mathrm{BP}$ ); both curves show a step in the warming trend at ca. $18 \mathrm{ka} \mathrm{BP}$ and centennialscale breaks in the warming trend centred at ca. $17.2 \mathrm{ka} \mathrm{BP}$, and at ca. 15.8 ka BP (these features can also be seen in Fig. 3d, persisting at filter-widths $>120 \mathrm{yr}$ ). The major timing differences between the records are delayed onset of the ACR and post-ACR warming at EDC compared to the composite. If real, this delay may represent a more rapid response of the near-coastal records used in the composite to the observed changes in Southern Ocean conditions (e.g. Anderson et al., 2009) and/or sea ice extent (e.g. Bianchi and Gersonde, 2004), which can cause changes in $\delta^{18} \mathrm{O}_{\text {ice }}$ by affecting cyclogenesis, the path of storm tracks, and the seasonal balance of precipitation (Noone and Simmonds, 2004). Alternately, the timing difference between the EDC and composite curves may simply reflect timescale uncertainties. Interestingly, LD, which has the earliest ACR onset, is also the lowest latitude of the records and closest to the Southern Ocean.

Turning now to the relative timing of north-south climate variations, Fig. 5 shows the Antarctic composite and the North Greenland Ice Core Project (NGRIP) $\delta^{18} \mathrm{O}_{\text {ice }}$ record (NGRIP members, 2004) through the period 11 to $20 \mathrm{ka} \mathrm{BP}$, interpreted as a proxy for climate in the broader North Atlantic region (hereafter, the "north"). We refrain from constructing a Greenland ice core composite since the main climate transitions (the onsets of which are defined in the INTIMATE climate event stratigraphy of Lowe et al. (2008)) are already simultaneous between the Greenland records when studied at $20 \mathrm{yr}$ time resolution (Rasmussen et al., 2008).

Coloured vertical bands in Fig. 5 illustrate significant warming and cooling trends in the Antarctic composite (hereafter the "south"), the timings of these features are also listed in Table 4. Significant deglacial warming begins in the south at $18.98 \pm 0.50 \mathrm{kaBP}$ on all timescales, and we therefore define this as the start of deglaciation. However, the warming trend then falters at $18.68 \mathrm{ka} \mathrm{BP}$, before resuming strongly and again on all timescales at $17.90 \pm 0.38 \mathrm{ka} \mathrm{BP}$. In the north, stadial conditions (GS-2) prevail until the abrupt warming of the Bølling onset at $14.64 \mathrm{kaBP}$; it has been previously proposed that the ACR onset also happened at around this time (Blunier and Brook, 2001, EPICA c.m.,
2006). However, the issue of which came first (of critical importance in separating cause and effect) is debated (Morgan et al., 2002) and has been complicated by the nonconsistent timescales previously used for individual Antarctic cores. Using the composite, we see that the end of the significant deglacial warming trend in the south, at $14.80 \pm 0.20 \mathrm{kaBP}$, and the start of significant ACR cooling, at $14.60 \pm 0.20 \mathrm{ka} \mathrm{BP}$, tightly bracket the Bølling onset. This synchrony of trend change in the south with transition in the north supports the view that the two events are coupled.

Progressing through the deglaciation, we find evidence for north-south climate coupling on sub-millennial timescales. The period of significant cooling within the ACR $(14.60 \pm 0.20 \mathrm{kaBP}$ to $14.14 \pm 0.20 \mathrm{ka} \mathrm{BP}$; dark blue band, Fig. 5) coincides tightly with the pronounced warmth of the Bølling (GI-1e). The coherence of the southern cooling trend during this interval implies that it was communicated relatively rapidly and uniformly around the Antarctic continent. Numerical models (e.g. Liu et al., 2009) and recent proxy-based observations from a south Atlantic sediment core (Barker et al., 2010) suggest that the pronounced Bølling warmth was associated with an "overshoot" of the AMOC and a southward expansion of the North Atlantic Deepwater cell. During this "overshoot", when heat release in the North Atlantic was at its strongest, our results suggest that heat flux away from the south was also at its strongest.

The initial Bølling warmth deteriorates through the Allerød and is punctuated by abrupt sub-millennial scale cooling events, including the Older Dryas (GI-1d) and the Intra-Allerød Cold Period (IACP or GI-1b) (Fig. 5). Results from a sediment core south of Iceland suggest that these sub-millennial cold events coincide with periods of increased meltwater flux to the North Atlantic (Thornalley et al., 2010). Changes in the trend in the Antarctic composite also occur close to the times of these sub-millennial cold events. Significant ACR cooling in the south ends around the time of the Older Dryas in the north. This is followed by a ca. $1000 \mathrm{yr}$ interval in the south during which there is no coherent Antarctic-wide warming or cooling trend. This interval is coincident with the Allerød stage GI-1c, which is not as warm as the Bølling (GI-1e) or the Holocene, a point we 


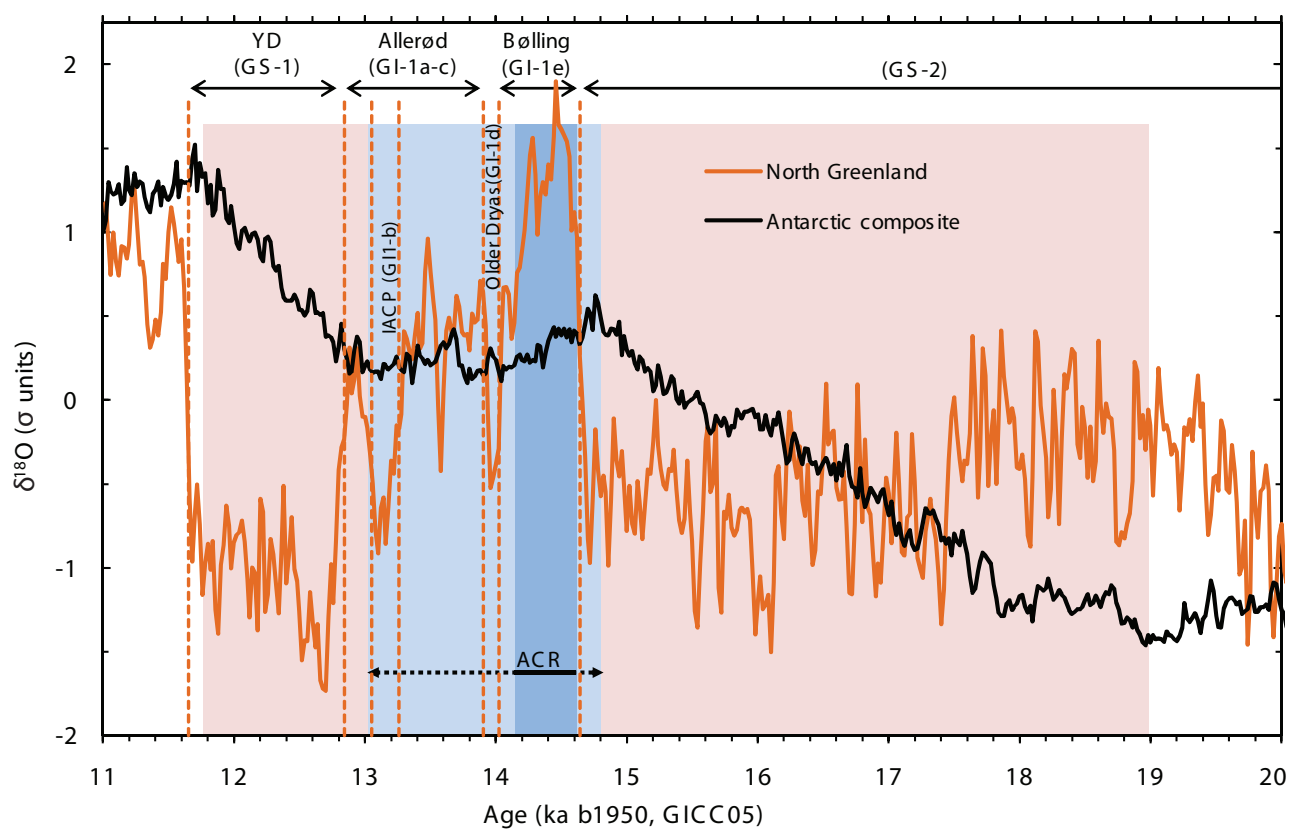

Fig. 5. A comparison of the pattern and timing of climate change in the Antarctic and North Atlantic regions during the last deglaciation: the Antarctic composite $\delta^{18} \mathrm{O}_{\text {ice }}$ record and the North Greenland (NGRIP) $\delta^{18} \mathrm{O}_{\text {ice }}$ record. Vertical pink bands correspond to periods of significant Antarctic warming, vertical light blue bands correspond to a pause in Antarctic warming, and the vertical dark blue band corresponds to significant Antarctic cooling. The minimum duration of the ACR is the period spanned by the dark blue band, the maximum duration of the ACR also includes the periods spanned by the light blue bands (as marked by the solid and dashed horizontal lines below the ACR label). Dashed vertical orange lines and labels at the top of the figure show the exact timing of the North Atlantic INTIMATE climate stages (Lowe et al., 2008).

return to below. The exact timing of the resumption of postACR warming in the south is difficult to pinpoint and appears variable between the different cores (Fig. 1). Significant post-ACR warming resumes at $\mathrm{LD}$ at $13.94 \pm 0.11 \mathrm{kaBP}$, at the start of the Allerød or possibly during the Older Dryas (GI-1d). Post-ACR warming also begins at Byrd during the Allerød (Fig. 1c), as noted previously by Blunier and Brook (2001). Looking to the composite for the best representation of the Antarctic-wide signal, warming is first detected at the $120 \mathrm{yr}$ filter-width at $13.02 \pm 0.20 \mathrm{kaBP}$ (Fig. 3d). This would place the resumption of warming coincident with GI$1 \mathrm{~b}$ (IACP) or GI-1a in the north. However, it is not until $12.74 \pm 0.20 \mathrm{kaBP}$ that warming is finally seen on all timescales.

According to the current concept of north-south climate coupling, the resumption of southern warming at the end of the ACR was triggered by the onset of the YD stadial in the north (at $12.85 \mathrm{ka} \mathrm{BP}$ ) (e.g. Denton et al, 2010; Kaplan et al., 2010). Our results, within dating uncertainties, remain consistent with this view but offer new detail. Although the entire Allerød period is generally regarded as a mild climatic period in Greenland, it is substantially cooler than the $\mathrm{B} \varnothing l$ ling, as noted above. In fact, the NGRIP $\delta^{18} \mathrm{O}_{\text {ice }}$ values during the IACP are similar to the pre-Bølling glacial values. Hence, the suggestion that warming may have already resumed in the south during the later stages of the Allerød, and prior to the $\mathrm{YD}$, is not inconsistent with the bipolar seesaw concept. Despite some ambiguity about the exact timing of the resumption of warming, our results show clearly that the YD does coincide with an interval of maximum warming around most of the Antarctic continent. The southern warming finally terminates at $11.76 \pm 0.22 \mathrm{kaBP}$, synchronous within dating uncertainties with the abrupt Holocene onset in the north at $11.65 \mathrm{kaBP}$.

Our main results are summarized as follows: firstly, trend changes in the south are aligned with millennial and/or submillennial climate transitions in the north; and secondly, the coldest (warmest) stages of the deglaciation in the north are aligned with the intervals of significant warming (cooling) in the south. This opposing climate behaviour between the hemispheres is consistent with a bipolar seesaw operating with minimal time lag in the transmission of climate signals between the high latitudes of both hemispheres.

Two different (but not mutually exclusive) mechanisms have previously been advanced to explain north-south climate coupling during the deglaciation. The first calls on the bipolar ocean seesaw, whereby weakening of the AMOC during GS-2 and the YD, due to freshwater discharge into the North Atlantic (Ganopolski and Rahmstorf, 2001; McManus et al., 2004), reduces both northward ocean heat 
transport and deepwater production in the North Atlantic, thereby stimulating deepwater formation and warming in the south (Broecker, 1998; Stocker and Johnsen, 2003). A variant of this first mechanism proposes that the strengthening of the AMOC was forced from the south by freshwater perturbations to the Southern Ocean linked to sea ice retreat (Bianchi and Gersonde, 2004; Knorr and Lohmann, 2003) or freshwater discharge from the Antarctic Ice Sheet (Weaver et al., 2003). However, recent model experiments have questioned the efficacy of such "southern triggers", suggesting that freshwater forcing in the south may lead to local cooling but has little effect on the strength of the AMOC or on temperatures in the north (Stouffer et al., 2007; Swingedouw et al., 2009). The second mechanism invokes an atmospheric teleconnection, whereby North Atlantic cooling during GS2 and the YD forces a southward shift of the Intertropical Convergence Zone, which in turn strengthens the southern westerlies and/or displaces them southward (Anderson et al., 2009 and references therein). Under this mechanism, the increased intensity of the westerlies is thought to warm the Southern Ocean and Antarctica through a combination of increased wind-driven upwelling, dissipation of sea ice via northward Ekman transport, and increased southward eddy transport of heat (Denton et al., 2010 and references therein).

What can our results say about these mechanisms? When considering bipolar coupling during the deglaciation, division of climate in the North Atlantic into three stages (GS-2, $\mathrm{B}-\mathrm{A}$, and YD) may be too simplistic; we find evidence that the sub-millennial climate transitions within the B-A (suggested to be linked to freshwater forcing events (Thornalley et al., 2010)) may also couple with climate variations in the south. Importantly, the observed timescales of north-south coupling require a mechanism capable of rapid signal transmission between the hemispheres. Fast-acting atmospheric teleconnections clearly meet this criteria. Rapid signal transmission can also be achieved via oceanic pathways through the action of internal ocean waves (e.g. Masuda et al., 2010). In the conceptual model of Stocker and Johnsen (2003), a rapid, wave-mediated seesaw in the Atlantic is coupled to a Southern Ocean heat reservoir. Under this "thermal bipolar seesaw", as soon as the north cools, heat begins accumulating in the south (and vice-versa). Therefore, despite the proposed 1000-1500 yr time constant of the Southern Ocean heat reservoir, the changes of slope in the south that we observe to accompany the abrupt changes in the north remain consistent with the Stocker and Johnsen (2003) model.

Our observations do not directly resolve the question of northern or southern forcing. Indeed, in a coupled system factors in both hemispheres may be important. Interestingly, the warming trends in at least two of the individual records used in the composite weaken well in advance of the Bølling onset, at LD ca. $15.30 \mathrm{kaBP}$ and at EDML ca. $16.2 \mathrm{kaBP}$ (see also Stenni et al., 2011), suggesting that warming in the south prior to the ACR in some parts of the continent may have reached a level at which freshwater and/or temperature forcings linked to sea ice retreat were weakening the overturning in the Southern Ocean and causing the local warming trend to falter. In this context, positive freshwater forcing due to deglacial warming in the south and reduced freshwater forcing at the end of $\mathrm{H} 1$ in the north may have superimposed and ultimately both contributed to the abrupt strengthening of the AMOC and the synchronous ACR and Bølling onsets. A similar concept was investigated in a recent model experiment (Lucas et al., 2010), which found higher amplitude responses of the AMOC when freshwater forcings of opposite sign were simultaneously applied to the deepwater formation areas in both hemispheres.

\section{Conclusions}

The composite Antarctic climate record derived here is robust (i.e. insensitive to exclusion of individual records) and reflects coherent circum-Antarctic climate changes through the deglacial period. The well-constrained methane ties allow co-registration of Antarctic and Greenland ice core climate records with a ca. $200 \mathrm{yr}$ uncertainty.

The records confirm the operation of a bipolar temperature seesaw and provide strong evidence that the mechanism involved is rapid and operates over millennial and sub-millennial timescales; Antarctic trend changes are seen as counterparts to each of the events in the Greenland climate sequence from the Bølling and Allerød through to the Younger Dryas and the onset of the Holocene. A key result is that the period of strongest Antarctic cooling directly coincides with the period of greatest northern warmth, the Bølling (GI-1e). The high resolution of the present study indicates that significant Antarctic cooling was largely complete by the start of the sub-millennial Greenland cold stage, the Older Dryas (GI-1d). This sub-millennial scale coupling argues that in a bipolar seesaw context, division of climate in the North Atlantic into three stages (GS-2, B-A, and YD) may be too simplistic. During the Allerød, climate conditions have already cooled substantially with respect to the Bølling, and in the south post-ACR warming has begun in at least two of the Antarctic records (LD and Byrd). In the composite, we see that a coherent Antarctic-wide resumption of warming is possibly underway by the later stages of the Allerød. The YD however, does mark the period of most rapid and uniform Antarctic warming. In terms of the bipolar seesaw, this result may imply that the heat balance between the hemispheres was already tipping toward southern warming as conditions in Greenland deteriorated through the Allerød.

The Antarctic composite also provides a useful tool for evaluating the deglacial climate records of individual cores, and specifically, the more weakly dated interior East Antarctic records. For example, the younger ACR onset in the EPICA Dome C record could reflect a lag in propagation from coast to interior, different distal source and transport 
effects, or it may be attributed to dating uncertainties, the refinement of which could be used to reassess the $\Delta$ age and accumulation relationships at these sites.

Similarly, individual site differences, such as the early cessation of the warming trend at LD (at $15.30 \mathrm{ka} \mathrm{BP}$ ) argue for local or regional influences. A question which requires further investigation is whether this early signal at LD and also the early break in the warming trend at EDML (at 16.2 ka BP) are signs of changing Southern Ocean wind or sea-ice conditions that are precursors to the later abrupt onset of the Bølling and the strong, regionally coherent ACR cooling.

The data sets are available online at the Australian Antarctic Data Centre (http://data.aad.gov.au/) and at the World Data Centre for Paleoclimatology (http://www.ncdc.noaa. gov/paleo/).

\section{Appendix A}

\section{Application of the GICC05 time scale to the Byrd, Siple Dome and EDML records}

The Byrd, Siple Dome, Talos Dome, and EDML records were dated by previous authors by aligning variations in $\mathrm{CH}_{4}$ with similar variations in Greenland $\mathrm{CH}_{4}$ records from the GRIP and GISP2 ice cores. We adopt the previous dating of these records and, where necessary (Byrd and Siple Dome), transfer them to the common Greenland GICC05 timescale, as described below.

\section{A1 Byrd}

Byrd was previously synchronised with GRIP and GISP2 using fast methane variations (Blunier and Brook, 2001) (data from http://www.ncdc.noaa.gov/paleo/pubs/blunier2001/ blunier2001.html). We converted the Byrd $\delta^{18} \mathrm{O}_{\text {ice }}$ and $\mathrm{CH}_{4}$ records on their ss09 timescale to GICC05 in two steps:

1. converting the ss09 Byrd ages to GRIP depths via the ss09 age-depth relation (Johnsen et al., 1997) (data from http://www.iceandclimate.nbi.ku.dk/data/);

2. converting GRIP depths to GICC05 ages by linear interpolation between the GICC05 GRIP age-depth ties (Rasmussen et al., 2008) (data from http://www. iceandclimate.nbi.ku.dk/data/).

The resulting GICC05 timescale for Byrd $\delta^{18} \mathrm{O}_{\text {ice }}$ was compared with an independent transfer of Byrd onto GICC05 by Thomas Blunier (personal communication, February 2010) and agreed with maximum discrepancy in the interval 9 to $21 \mathrm{ka} \mathrm{BP}$ of $36 \mathrm{yr}$ and average discrepancy of $3.4 \mathrm{yr}$.

We adopt the previously reported Byrd $\Delta$ age and Byrd to GISP2/GRIP $\mathrm{CH}_{4}$ correlation errors (Blunier and Brook, 2001) (data from: http://www.sciencemag.org/cgi/content/ full/sci;291/5501/109/DC1). The dating error introduced in the transfer from the GISP2 layer counted depth scale to the
GICC05 timescale is negligible compared to the $\Delta$ age and correlation errors, and is therefore not considered. The RMS sum of the Byrd $\Delta$ age error and $\mathrm{CH}_{4}$ correlation error during the early middle and late stages of the deglaciation are listed in Table 3.

The average temporal resolution of the Byrd $\delta^{18} \mathrm{O}_{\text {ice }}$ data for the interval 9 to $21 \mathrm{ka} \mathrm{BP}$ was $41 \mathrm{yr}$.

\section{A2 Siple Dome}

Siple Dome was previously synchronised with GISP2 using fast methane variations (data from: http://nsidc.org/data/ waiscores/pi/brook.html) (Brook et al., 2005). As $\delta^{18} \mathrm{O}_{\text {ice }}$ values for Siple Dome during the deglaciation were not available, we used appropriately scaled $\delta \mathrm{D}_{\text {ice }}$ i.e. $(\delta \mathrm{D}-10) / 8$ (on advice of James White and Edward Brook, pers. comm. March 2011). We converted the Siple Dome $\delta \mathrm{D}_{\text {ice }}$ and $\mathrm{CH}_{4}$ records, which were reported on the GISP2 layer counted timescale to GICC05 in two steps:

1. converting the Siple Dome ages to GISP2 depths via the GISP2 layer counted depth scale (Meese et al., 1997) (data from: http://www.ncdc.noaa.gov/paleo/icecore/ greenland/summit/document/gispdpth.htm);

2. converting GISP2 depths to GICC05 ages by linear interpolation between the GICC05 GISP2 age-depth ties (Rasmussen et al., 2008) (data from: http://www. iceandclimate.nbi.ku.dk/data/).

We adopt the previously reported $\Delta$ age and $\mathrm{CH}_{4}$ correlation errors (Brook et al., 2005) (data from: http://nsidc.org/ data/waiscores/pi/brook.html). The dating error introduced in the actual transfer from the GISP2 layer counted depth scale to the GICC05 timescale is negligible compared to the $\Delta$ age and correlation errors, and is therefore not considered. The RMS sum of the $\Delta$ age and $\mathrm{CH}_{4}$ correlation errors in the Siple Dome data during the early middle and late stages of the deglaciation are listed in Table 3.

The average temporal resolution of the Siple Dome data for the interval 9 to $21 \mathrm{ka} \mathrm{BP}$ was $32 \mathrm{yr}$.

\section{A3 Talos Dome}

The Talos Dome timescale (Buiron et al., 2011) is consistent with GICC05. Standard dating errors during the early middle and late stages of the deglaciation are listed in Table 3.

The average temporal resolution of the Talos Dome data for the interval 9 to $21 \mathrm{ka} \mathrm{BP}$ was $39 \mathrm{yr}$.

\section{A4 EDML}

The recently revised EDML timescale (Lemieux-Dudon et al., 2010) is consistent with GICC05. The revised EDML timescale, $\delta^{18} \mathrm{O}_{\text {ice }}$ and $\mathrm{CH}_{4}$ data and standard dating errors were obtained from Benedicte Lemieux-Dudon (personal 
communication, February 2010). Standard dating errors during the early middle and late stages of the deglaciation are listed in Table 3.

The average temporal resolution of the EDML data for the interval 9 to $21 \mathrm{ka} \mathrm{BP}$ was $15 \mathrm{yr}$.

Acknowledgements. This work was assisted by the Australian Government's Cooperative Research Centres Programme, through the Antarctic Climate and Ecosystems Cooperative Research Centre. Funding support in France was provided by the LEFE programme of the Institut National des Sciences de l'Univers (INSU) and by the project ANR-07-BLAN-0125 of Agence Nationale de la Recherche. S.O.R. gratefully acknowledges support from an Inge Lehmann grant. We thank Edward Brook and Eric Wolff for their constructive reviews.

Edited by: H. Fischer

\section{References}

Andersen, K. K., Ditlevsen, P. D., Rasmussen, S. O., Clausen, H. B., Vinther, B. M., Johnsen, S. J., and Steffensen, J. P.: Retrieving a common accumulation record from Greenland ice cores for the past 1800 years, J. Geophys. Res., 111, D15106, doi:10.1029/2005JD006765, 2006a.

Andersen, K. K., Svensson, A., Johnsen, S. J., Rasmussen, S. O., Bigler, M., Rothlisberger, R., Ruth, U., Siggaard-Andersen, M., Peder Steffensen, J., Dahl-Jensen, D., Vinther, B. M., and Clausen, H. B.: The Greenland Ice Core Chronology 2005, 15 42 ka. Part 1: constructing the time scale, Quaternary Sci. Rev., 25, 3246-3257, doi:10.1016/j.quascirev.2006.08.002, 2006 b.

Anderson, R. F., Ali, S., Bradtmiller, L. I., Nielsen, S. H. H., Fleisher, M. Q., Anderson, B. E., and Burckle, L. H.: WindDriven Upwelling in the Southern Ocean and the Deglacial Rise in Atmospheric $\mathrm{CO}_{2}$, Science, 323, 1143-1448, 2009.

Barker, S., Knorr, G., Vautravers, M. J., Diz, P., and Skinner, L. C.: Extreme deepening of the Atlantic circulation during deglaciation, Nat. Geosci., 3, 567-571, 2010.

Barnola, J. M., Pimienta, P., Raynaud, D., and Korotkevich, Y. S.: CO2-climate relationship as deduced from the Vostok ice core: a re-examination based on new measurements and on a re-evaluation of the air dating, Tellus Ser. B., 43, 83-90, 1991.

Bianchi, C. and Gersonde, R.: Climate evolution at the last deglaciation: the role of the Southern Ocean, Earth Planet. Sci. Lett., 228, 407-424, 2004.

Blunier, T. and Brook, E. J.: Timing of millennial-scale climate change in Antarctica and Greenland during the last glacial period, Science, 291, 109-112, doi:10.1126/science.291.5501.109, 2001.

Blunier, T., Chappellaz, J., Schwander, J., Dällenbach, A., Stauffer, B., Stocker, T. F., Raynaud, D., Jouzel, J., Clausen, H. B., Hammer, C. U., and Johnsen, S. J.: Asynchrony of Antarctic and Greenland climate change during the last glacial period, Nature, 394, 739-743 1998.

Broecker, W.: Palaeocean circulation during the last deglaciation: A bipolar seesaw?, Paleoceanography, 13, 119-121, 1998.

Brook, E. J., White, J. W. C., Schilla, A. S. M., Bender, M. L., Barnett, B. Severinghaus, J. P., Taylor, K. C., Alley, R. B., and Steig, E. J.: Timing of millennial-scale climate change at Siple
Dome, West Antarctica, during the last glacial period, Quat. Sci. Rev., 24, 1333-1343, 2005.

Buiron, D., Chappellaz, J., Stenni, B., Frezzotti, M., Baumgartner, M., Capron, E., Landais, A., Lemieux-Dudon, B., MassonDelmotte, V., Montagnat, M., Parrenin, F., and Schilt, A.: TALDICE-1 age scale of the Talos Dome deep ice core, East Antarctica, Clim. Past, 7, 1-16, doi:10.5194/cp-7-1-2011, 2011.

Chaudhuri, P. and Marron, J. S.: SiZer for Exploration of Structures in Curves, J. Am. Stat. Assoc., 94, 807-823, (A SiZer script for MatLab can be obtained from http://www.unc.edu/ marron/ marron_software.html), 1999.

Delmotte, M., Raynaud, D., Morgan, V., and Jouzel, J.: Climatic and glaciological information inferred from air content measurements of a Law Dome (East Antarctica) ice core, J. Glaciol., 45, 255-263, 1999.

Denton, G. H., Anderson, R. F., Toggweiler, J. R., Edwards, R. L., Schaefer, J. M., and Putnam, A. E.: The last glacial termination, Science, 328, 1652-1656, 2010.

EPICA community members: One-to-one coupling of glacial climate variability in Greenland and Antarctica, Nature, 444, 195198, 2006.

Ganopolski, A. and Rahmstorf, S.: Rapid changes of glacial climate simulated in a coupled climate model, Nature, 409, 153158, 2001.

Goujon, C., Barnola, J.-M., and Ritz, C.: Modeling the densification of polar firn including heat diffusion: Application to close-off characteristics and gas isotopic fractionation for Antarctica and Greenland sites, J. Geophys. Res., 108, 4792, doi:10.1029/2002JD003319, 2003.

Johnsen, S. J., Clausen, H. B., Dansgaard, W., Gundestrup, N. S., Hammer, C. U., Andersen, U., Andersen, K. K., Hvidberg, C. S., Dahl-Jensen, D., Steffensen, J. P., Shoji, H., Sveinbjörnsdóttir, Á. E., White, J., Jouzel, J., and Fisher, D.: The $\delta^{18} \mathrm{O}$ record along the Greenland Ice Core Project deep ice core and the problem of possible Eemian climatic instability, J. Geophys. Res., 102, 26397-26410, doi:10.1029/97JC00167, 1997.

Jones, P. D., Briffa, K. R., Osborn, T. J., Lough, J. M., van Ommen, T. D., Vinther, B. M., Luterbacher, J., Wahl, E. R., Zwiers, F. W., Mann, M. E., Schmidt, G. A., Ammann, C. M., Buckley, B. M., Cobb, K. M., Esper, J., Goosse, H., Graham, N., Jansen, E., Kiefer, T., Kull, C., Küttel, M., Mosley-Thompson, E., Overpeck, J. T., Riedwyl, N., Schulz, M., Tudhope, A. W., Villalba, R., Wanner, H., Wolff, E., and Xoplaki, E.: High-resolution paleoclimatology of the last millennium: a review of current status and future prospects, Holocene, 19, 3-49, 2009.

Jouzel, J., Masson, V., Cattani, O., Falourd, S., Stievenard, M., Stenni, B., Longinelli, A., Johnsen, S. J., Steffenssen, J. P., Petit J. R., Schwander, J., Souchez, R., and Barkov, N. I.: A new 27 ky high resolution East Antarctic climate record, Geophys. Res. Lett., 28, 3199-3202, doi:10.1029/2000GL012243, 2001.

Kaplan, M. R., Schaefer, J. M., Denton, G. H., Barrell, D. J. A., Chinn, T. J. H., Putnam, A. E., Andersen, B. G., Finkel, R. C., Schwartz, R., and Doughty, A. M.: Glacier retreat in New Zealand during the Younger Dryas stadial, Nature, 467, 194-197, 2010.

Knorr, G. and Lohmann, G.: Southern Ocean origin for the resumption of Atlantic thermohaline circulation during deglaciation, $\mathrm{Na}-$ ture, 424, 532-535, 2003.

Landais, A., Barnola, J. M., Kawamura, K., Caillon, N., Delmotte, 
M., van Ommen, T., Dreyfus, G., Jouzel, J., Masson-Delmotte, V., Minster, B., Freitag, J., Leuenberger, M., Schwander, J., Huber, C., Etheridge, D., and Morgan, V.: Firn-air $\delta^{15} \mathrm{~N}$ in modern polar sites and glacial interglacial ice: a model-data mismatch during glacial periods in Antarctica?, Quaternary Sci. Rev., 25, 49-62, doi:10.1016/j.quascirev.2005.06.007, 2006.

Lemieux-Dudon, B., Blayo, E., Petit, J.-R., Waelbroeck, C., Svensson, A, Ritz, C., Barnola, J.-M., Narcisi, B. M., and Parrenin, F.: Consistent dating for Antarctic and Greenland ice cores, Quat. Sci. Rev., 29, 8-20, 2010.

Liu, Z., Otto-Bliesner, B. L., He, F., Brady, E. C., Tomas, R., Clark, P. U., Carlson, A. E., Lynch-Stieglitz, J., Curry, W., Brook, E., Erickson, D., Jacob, R., Kutzbach, J., and Cheng, J.: Transient Simulation of Last Deglaciation with a New Mechanism for Bølling-Allerød Warming, Science, 325, 310-314, doi:10.1126/science.1171041, 2009.

Lowe, J. J., Rasmussen, S. O., Björck, S., Hoek, W. Z., Steffensen, J. P., Walker, M. J. C., and Yu, Z. C.: Synchronisation of palaeoenvironmental events in the North Atlantic region during the Last Termination: a revised protocol recommended by the INTIMATE group, Quat. Sci. Rev., 27, 6-17, 2008.

Lucas, M. A., Hirschi J. J.-M., and Marotzke, J.: Response of the meridional overturning circulation to variable buoyancy forcing in a double hemisphere basin, Clim. Dynam., 34, 615-627, 2010.

Masuda, S., Awaji, T., Sugiura, N., Matthews, J. P., Toyoda, T., Kawai, Y., Doi, T., Kouketsu, S., Igarashi, H., Katsumata, K., Uchida, H., Kawano, T., and Fukasawa, M.: Simulated Rapid Warming of Abyssal North Pacific Waters, Science, 329, 319322, doi:10.1126/science.1188703, 2010.

McManus, J. F., Francois, R., Gherardi, J.-M., Keigwin, L. D., and Brown-Leger, S.: Collapse and rapid resumption of Atlantic meridional circulation linked to deglacial climate changes, Nature, 428, 834-837, 2004.

Meese, D. A., Gow, A. J., Alley, R. B., Zielinski, G. A., Grootes, P. M., Ram, M., Taylor, K. C., Mayewski, P. A., and Bolzan, J. F.: The Greenland Ice Sheet Project 2 depth-age scale: Methods and results, J. Geophys. Res., 102, 26411-26424, doi:10.1029/97JC00269, 1997.

Monnin, E., Steig, E. J., Siegenthaler, U., Kawamura, K., Schwander, J., Stauffer, B., Stocker, T. F., Morse, D. L., Barnola, J.M., Bellier, B., Raynaud, D., and Fischer, H.: Evidence for substantial accumulation rate variability in Antarctica during the Holocene, through synchronization of $\mathrm{CO}_{2}$ in the Taylor Dome, Dome C and DML ice cores, Earth Planet. Sci. Lett., 224, 45-54, doi:10.1016/j.eps1.2004.05.007, 2004.

Morgan, V., Delmotte, M., van Ommen, T. D., Jouzel, J., Chappellaz, J., Woon, S., Masson-Delmotte, V., and Raynaud, D.: Relative timing of deglacial climate events in Antarctica and Greenland, Science, 297, 1862-1864, doi:10.1126/science.1074257, 2002.

NGRIP members: High-resolution record of Northern Hemisphere climate extending into the Last Interglacial period, Nature, 431, 147-151, 2004.

Noone, D. and Simmonds, I.: The sea ice control on water isotope transport to Antarctica and implications for ice core interpretation, J. Geophys. Res., 109, D07105, doi:10.1029/2003JD004228, 2004.

Parrenin, F., Barnola, J.-M., Beer, J., Blunier, T., Castellano, E., Chappellaz, J., Dreyfus, G., Fischer, H., Fujita, S., Jouzel, J.,
Kawamura, K., Lemieux-Dudon, B., Loulergue, L., MassonDelmotte, V., Narcisi, B., Petit, J.-R., Raisbeck, G., Raynaud, D., Ruth, U., Schwander, J., Severi, M., Spahni, R., Steffensen, J. P., Svensson, A., Udisti, R., Waelbroeck, C., and Wolff, E.: The EDC3 chronology for the EPICA Dome C ice core, Clim. Past, 3, 485-497, doi:10.5194/cp-3-485-2007, 2007.

Rasmussen, S. O., Seierstad, I. K., Andersen, K. K., Bigler, M., Dahl-Jensen, D., and Johnsen, S. J.: Synchronization of the NGRIP, GRIP, and GISP2 ice cores across MIS 2 and palaeoclimatic implications, Quaternary Sci. Rev., 27, 18-28, doi:10.1016/j.quascirev.2007.01.016, 2008.

Rasmussen S. O., Seierstad, I. K., Andersen, K. K., Bigler, M., Dahl-Jensen, D., and Johnsen, S. J.: Synchronization of the NGRIP, GRIP, and GISP2 ice cores across MIS 2 and palaeoclimatic implications, Quuaternary Sci. Rev., 27, 18-28, 2008.

Shakun, J. D. and Carlson, A. E.: A global perspective on Last Glacial Maximum to Holocene climate change, Quaternary Sci. Rev., 29, 1801-1816, 2010.

Sowers, T. and Bender, M.: Climate records covering the last deglaciation, Science, 269, 210-214, 1995.

Stanford, J. D., Rohling, E. J., Hunter, S. E., Roberts, A. P., Rasmussen, S. O., Bard, E., McManus, J., and Fairbanks, R. G.: Timing of meltwater pulse 1a and climate responses to meltwater injections, Paleoceanography, 21, PA4103, doi:10.1029/2006PA001340, 2006.

Steffensen, J. P., Andersen, K. K., Bigler, M., Clausen, H. B., DahlJensen, D., Fischer, H., Goto-Azuma, K., Hansson, M., Johnsen, S. J., Jouzel, J., Masson-Delmotte, V., Popp, T., Rasmussen, S. O., Röthlisberger, R., Ruth, U., Stauffer, B., Siggaard-Andersen, M., Sveinbjörnsdóttir, Á . E., Svensson, A., and White, J. W. C.: High-Resolution Greenland Ice Core Data Show Abrupt Climate Change Happens in Few Years, Science, 321, 680-684, doi:10.1126/science.1157707, 2008.

Stenni, B., Buiron, D., Frezzotti, M., Albani, S., Barbante, C., Bard, E., Barnola, J. M., Baroni, M., Baumgartner, M., Bonazza, M., Capron, E., Castellano, E., Chappellaz, J., Delmonte, B., Falourd, S., Genoni, L., Iacumin, P., Jouzel, J., Kipfstuhl, S., Landais, A., Lemieux-Dudon, B., Maggi, V., Masson-Delmotte, V., Mazzola, C., Minster, B., Montagnat, M., Mulvaney, R., Narcisi, B., Oerter, H., Parrenin, F., Petit, J. R., Ritz, C., Scarchilli, C., Schilt, A., Schúpbach, S., Schwander, J., Selmo, E., Severi, M., Stocker, T. F., and Udisti, R.: Expression of the bipolar seesaw in Antarctic climate records during the last deglaciation, Nat. Geosci., 4, 46-49, doi:10.1038/ngeo1026, 2011.

Stocker, T. F. and Johnsen, S. J.: A minimum thermodynamic model for the bipolar seesaw, Paleoceanography, 18, PA000920, doi:10.1029/2003PA000920, 2003.

Stouffer, R. J., Seidov, D., and Haupt, B. J.: Climate response to external sources of freshwater: North Atlantic versus the Southern Ocean, J. Climate, 20(3), 436-448, 2007.

Swingedouw, D., Fichefet, T., Goosse, H., and Loutre, M. F.: Impact of transient freshwater releases in the Southern Ocean on the AMOC and climate, Clim. Dyn., 33, 365-381, doi:10.1007/s00382-008-0496-1, 2009.

Thornalley, D. J. R., McCave, I. N., and Elderfield, H.: Freshwater input and abrupt deglacial climate change in the North Atlantic, Palaeoceanography, 25, PA1201, doi:10.1029/2009PA001772, 2010.

Timmermann, R., Le Brocq, A., Deen, T., Domack, E., Dutrieux, 
P., Galton-Fenzi, B., Hellmer, H., Humbert, A., Jansen, D., Jenkins, A., Lambrecht, A., Makinson, K., Niederjasper, F., Nitsche, F., Nøst, O. A., Smedsrud, L. H., and Smith, W. H. F.: A consistent data set of Antarctic ice sheet topography, cavity geometry, and global bathymetry, Earth Syst. Sci. Data, 2, 261-273, doi:10.5194/essd-2-261-2010, 2010.

van Ommen, T. D. and Morgan V. I.: Calibrating the ice core paleothermometer using seasonality, J. Geophys. Res., 102, 93519357, 1997.

van Ommen, T. D., Morgan V. I., and Curran M. A. J.: Deglacial and Holocene changes in accumulation at Law Dome, edited by: Jacka, T. H., Ann. Glaciol., 39, 359-365, 2004.
Weaver, A. J., Saenko, O. A., Clark, P. U., and Mitrovica, J. X. Meltwater Pulse 1A from Antarctica as a Trigger of the BøllingAllerød Warm Interval, Science, 299, 1709-1713, 2003.

White, J. W. C., Barlow, L. K., Fisher, D., Grootes, P., Jouzel, J., Johnsen, S. J., Stuiver, M., and Clausen, H.: The climate signal in the stable isotopes of snow from Summit, Greenland: results of comparisons with modern climate observations, J. Geophys. Res., 102(26), 425-39, 1997. 